Meta

Journal des traducteurs

Translators' Journal

\title{
Problems in Interpretation
}

\section{Elizabeth Biscaye}

Volume 38, numéro 1, mars 1993

La traduction et l'interprétation dans le nord du Canada

Translation and Interpretation in Northen Canada

URI : https://id.erudit.org/iderudit/002085ar

DOI : https://doi.org/10.7202/002085ar

Aller au sommaire du numéro

Éditeur(s)

Les Presses de l'Université de Montréal

ISSN

0026-0452 (imprimé)

1492-1421 (numérique)

Découvrir la revue

Citer cet article

Biscaye, E. (1993). Problems in Interpretation. Meta, 38(1), 101-103.

https://doi.org/10.7202/002085ar

\section{Résumé de l'article}

Le gouvernement des Territoires du Nord-Ouest fournit à l'heure actuelle des services de traduction et d'interprétation en français, en anglais et en sept langues aborigènes du Nord. Jusqu'à tout récemment, l'interprétation simultanée n'était offerte qu'en inuktitut; suite à la demande croissante et à l'amélioration des programmes d'enseignement, l'interprétation est maintenant offerte dans les langues dénés. L'interprétation "à relais", caractéristique unique des services d'interprétation des Territoires du Nord-Ouest, joue un rôle important en raison des multiples langues utilisées sur une base régulière. On discute ici de l'importance de l'interprétation simultanée dans les Territoires du Nord-Ouest et des problèmes auxquels doivent faire face les interprètes.
Ce document est protégé par la loi sur le droit d'auteur. L'utilisation des services d'Érudit (y compris la reproduction) est assujettie à sa politique d'utilisation que vous pouvez consulter en ligne.

https://apropos.erudit.org/fr/usagers/politique-dutilisation/ 


\title{
PROBLEMS IN INTERPRETATION
}

\author{
ELIZABETH BISCAYE \\ G.N.W.T. Culture and Communications, \\ Yellowknife, Northwest Territories, Canada
}

\begin{abstract}
Résumé
Le gouvernement des Territoires du Nord-Ouest fournit à l'heure actuelle des services de traduction et d'interprétation en français, en anglais et en sept langues aborigènes du Nord. Jusqu'à tout récemment, l'interprétation simultanée n'était offerte qu'en inuktitut; suite à la demande croissante et à l'amélioration des programmes d'enseignement, l'interprétation est maintenant offerte dans les langues dénés. L'interprétation «à relais", caractéristique unique des services d'interprétation des Territoires du Nord-Ouest, joue un rôle important en raison des multiples langues utilisées sur une base régulière. On discute ici de l'importance de l'interprétation simultanée dans les Territoires du Nord-Ouest et des pro. blèmes auxquels doivent faire face les interprètes.
\end{abstract}

\section{Abstract}

The Government of the Northwest Territories currently provides interpreting and translating services in French, English and seven northern aboriginal languages. Simultaneous interpreting was, until recently, only delivered in Inuktitut. With increasing demand, and improvements to training programs, it is now provided in the Dene languages as well. Relay interpreting, a unique feature to the NWT interpreting services, plays an important role due to the multiple languages dealt with on a regular basis. This paper will discuss the importance of, and problems encountered with, simultaneous interpreting in the NWT.

Within the last few years, interpreters in the NWT have gained recognition as professionals. This is due in part to a better understanding of the role and responsibilities of interpreters by the public. People are now more aware of the difficulties an interpreter faces, especially in the NWT where there are nine official languages used on a daily basis.

This article will discuss a few of the difficulties encountered by aboriginal language interpreters in the NWT.

To begin, the interpretation of abstract concepts poses a problem to the interpreter. Today aboriginal residents of the North are being exposed to new and foreign concepts. However, because of their importance in the further development of the North, interpreters must deal with these concepts so that informed decisions can be made by the public. Try to imagine the difficulty an interpreter faces in trying to explain "cruise missiles" to a person who has no knowledge of what they are. Space is a concept outside the realm of an aboriginal person's knowledge, which is rooted in meteorological phenomena, and so attempting to translate the concept of a cruise missile in an aboriginal language is complicated.

The introduction of new technologies and social systems creates another problem for interpreters - lack of equivalent terminology. Interpreters have to develop terminology, sometimes in situations where they will be called upon to explain a phrase or term for which there are no equivalents in the aboriginal language or in English. Often the interpreter is required to learn about new technologies in order to interpret from English into 
an aboriginal language; or is called upon to interpret the speech of aboriginal elders which is more formal and conservative, and requires familiarity with words used by a different age set.

In a simultaneous interpreting situation, the interpreter does not have the luxury of time in which to research and consult with others in arriving at an equivalent term. This adds additional pressure, especially in situations which may have direct implications on the public. In this case, an interpreter uses the English term, and tries to define it to the best of his or her ability and understanding.

Another problem faced by the interpreter is the use of idioms and cliches which are in most cases not translatable in the aboriginal languages. For example, "throw the baby out with the bathwater" is a difficult idiom for aboriginal language speakers. Apart from not being able to interpret the intent, interpreters may have difficulty with the concept. In most cases, interpreters do not even attempt to interpret idioms and cliches.

The use of acronyms poses another problem for interpreters. Unless the interpreter is familiar with commonly used acronyms, he or she may encounter difficulties, because using the initials without explaining what they stand for may lead to an incomplete message being conveyed.

One problem common to any language is the speed of speech in simultaneous interpreting situations. It is difficult enough to maintain communication, to translate concepts and to relay these into another language - it is even more difficult when required to do so at a faster than normal rate. This may cause an interpreter to miss or omit an important detail.

Differences in word order between aboriginal languages and English also lead to difficulties for the interpreter. Often the interpreter must catch up with the speaker, which requires extra concentration.

There are other problems common to consecutive interpreting, especially legal interpreting. Legal interpreting requires concise interpretation with close attention to detail. For example, "he hit him' is difficult to translate. The interpreter must clarify how the action was carried out, because there are no terms in the aboriginal languages for "hit". It must be specified whether the hitting was done with a fist, with an open palm or with an object.

Another problem for legal interpreters is defining relationships. In the Dene languages, the word "brother" is not translatable. The interpreter must determine whether an older or younger brother is meant.

There is no gender differentiation in third person pronominal forms in aboriginal languages. This means that the context must be relied upon to disambiguate the reference. In English, the ambiguity in a sentence such as "he kicked his chair" is not present in the equivalent aboriginal language translation, where different pronominals refer to proximate and obviative third persons.

Dual forms also create difficulties. For example, "we went out" could mean two people or it could mean three or more people, and the verb stem would vary depending on number in aboriginal languages.

Another problem in interpreting involves describing objects. The verb used in the aboriginal language will depend on the type of object being described; for example, a long thin object such as a board will be described using a different verb stem than would be used to describe a rock.

Yet another common problem is dialect variation. The public has difficulty understanding interpreters who speak different dialects, however there are not enough interpreters to provide interpretation in every dialect for all situations. 
The aboriginal speaking interpreter also faces a conflict between his or her own cultural worldview, and his or her ethical responsibility as an interpreter interfacing between two different cultures.

In spite of all these problems, interpreters in the NWT have made great progress and, as noted, have gained recognition as professionals. Being aware of these problems will enable interpreters to identify solutions to deal with them. 